\title{
ХІРУРГІЧНЕ ЛІКУВАННЯ ХВОРИХ З ПРИВОДУ ХРОНІЧНОГО ПАНКРЕАТИТУ 3 БІЛІАРНОЮ ГІПЕРТЕНЗІЕЮ
}

\author{
І. М. Шевчук, В. І. Пилипчук, А. Д. Хруник, С. М. Гедзик \\ Івано-Франківський національний медичний університет
}

\section{SURGICAL TREATMENT OF CHRONIC PANCREATITIS WITH BILIARY HYPERTENSION}

\author{
I. M. Shevchuk, V. I. Pylypchuk, A. D. Khrunik, S. M. Gedzik \\ Ivano-Frankivsk National Medical University
}

\section{Ресрерат}

Проаналізовані результати лікування 25 хворих з приводу фіброзно-дегенеративного хронічного панкреатиту (ХП) з біліарною гіпертензією (БГ), у яких виконана операція Фрея. У 13 (52\%) хворих (група порівняння) здійснена класична операція Фрея з фрормуванням панкреатоєюноанастомозу (ПЄА) на петлі тонкої кишки, виключеній за Ру, у 4 (16\%) - операція Фрея 3 накладанням гепатикоєюноанастомозу (ГЄА). У 8 (32\%) хворих застосовано модифікацію операції Фрея, що передбачала фрормування ПЄА на ізольованому сегменті тонкої кишки, додаткового дуоденоєюноанастомозу з дистальним кінцем сегмента тонкої кишки, холецистектомію, фомування ГЄА бік у бік та міжкишкового анастомозу за Ру (основна група). Для інтраопераційного визначення тиску у позапечінкових жовчних протоках використовували оригінальну методику.

Віддалені результати проаналізовані у 13 пацієнтів. В групі порівняння показник фрізичного здоров'я (PHs) становив у середньому $(42,9 \pm 0,9)$ ум. од., психологічного здоров'я (MHs) - $(57,6 \pm 1,9)$ ум. од., вираженість больового синдрому $(\mathrm{BP})-(60,3 \pm 5,2)$ ум. од.; в основній групі РНs становив $(47,1 \pm 1,1)$ ум. од., MHs - $(61,5 \pm 1,5)$ ум. од., ВР - $(68,4 \pm 4,2)$ ум. од.

Запропонована модифрікація хірургічного лікування фіброзно-дегенеративного ХП з БГ має переваги, обнадійливі віддалені результати і може бути застосована у лікуванні таких хворих.

Ключові слова: хронічний фіброзно-дегенеративний панкреатит; біліарна гіпертензія; хірургічне лікування; результати.

Abstract

We analysed the results of treatment of 25 patients suffering from fibrous-degenerative chronic pancreatitis (CP) with biliary hypertension who underwent Frey's procedure. Control group consisted of $13(52 \%)$ patients who underwent classical Frey's procedure when Rouxen-Y pancreaticojejunostomy (PJS) was performed. 4 (16\%) patients were performed Frey's procedure with hepaticojejunostomy (HJS). Main group consisted of $8(32 \%)$ patients who underwent modified Frey's procedure when PJS was performed on isolated jejunal segment, together with duodenojejunostomy with the distal segment of jejunum, cholecystectomy, lateral to lateral HJS and interintestinal Roux-en-Y anastomosis. Original approach was used to evaluate the pressure in the extrahepatic biliary ducts. Long-term results were analyzed in 13 patients. In the control group mean Physical Health Summary score (PHs) was 42.9 \pm 0.9 , Mental Health Summary score (MHs) $-57.6 \pm 1.9$, Bodily Pain Scale score (BP) was $60.3 \pm 5.2$. In the main group PHs was $47.1 \pm 1.1$, MHs $61.5 \pm 1.5, \mathrm{BP}-68.4 \pm 4.2$.

The suggested modification of fibrous-degenerative CP surgery has advantages, demonstrates promising long-term results and may be used in such patients.

Keywords: chronic fibrous-degenerative pancreatitis; biliary hypertension; surgical treatment; results.

Анатомічний контакт підшлункової залози (ПЗ) з суміжними органами при прогресуванні ХП зумовлює виникнення позапанкреатичних ускладнень - порушення евакуації дванадцятипалої кишки (ДПК), БГ, тромбоз чи екстравазальну компресію вен спленопортомезентеріального конфлюенсу, спричинені поширеним фіброзом та запаленням ії головки [1, 2].

Порушення прохідності спільної жовчної протоки (СЖП) виявлене у 56,3\% хворих за ХП, обтураційна жовтяниця - у 22,2\%, жовтяниця в поєднанні 3 холангітом - у 6\% [3]. Порушення прохідності ДПК ускладнило перебіг захворювання у 16,3\% пацієнтів, препапілярний стеноз СЖП відзначали у 33\%, компресію брижової та ворітної вен 3 утворенням асциту - в 11,6\% [4]. За ускладнених форм ХП стеноз СЖП виникає у 30 - 60\% хворих, порушення прохідності ДПК - у 6 - 36\%, компресія брижової та ворітної вен - в 11 - 17\% [5]. Причиною обтураційної жовтяниці у хворих при ХП також може бути стискання дистальної частини СЖП фіброзно-зміненим «язичком» ПЗ [6].

Жовтяницю, що зникає після усунення запального процесу, спостерігають при загостренні захворювання. Жовтяниця може бути стійкою внаслідок вираженого фіброзу й кальцифікації головки ПЗ. У віддалені строки після оперативного втру- чання $з$ приводу ХП після дренувальних операцій БГ виникла у 25\%, після резекційних - у 8 - 9\% хворих [7].

Методом вибору хірургічного лікування ХП з БГ сьогодні вважають дуоденумзберігальну резекцію головки ПЗ (операцію Фрея, операцію Бегера та іiі Бернську модифікацію). Деякі автори стверджують, що при виконанні операції Фрея доцільно висікати «язичок» ПЗ, а при стенозі дистального відділу загальної печінкової протоки додатково формувати ГЕА [6]. Для усунення БГ пропонують резекційні втручання на ПЗ доповнювати накладанням біліодигестивних анастомозів за неможливості перидуктального висічення паренхіми ПЗ [3]. 
Інші дослідники оптимальним втручанням вважають Бернську модифікацію операції Бегера з формуванням інтрапанкреатичного жовчовідвідного анастомозу. На їх думку, екстрапанкреатичні шунтувальні операції показані за відсутності інших ускладнень ХП та неможливості виділення інтрапанкреатичної частини СЖП [8].

Дослідники відзначають переваги модифікованої операції Фрея: видалення не тільки вентральної частини головки ПЗ, а й більшої частини фіброзно-зміненої тканини іiі дорзальної частини, що, на думку авторів, забезпечує усунення порушення прохідності ДПК, БГ та портальної гіпертензії [9].

Біліарні ускладнення, що виникають у 2 - 18\% хворих після резекційних втручань на ПЗ, в тому числі 3 накладанням внутрішнього біліопанкреатичного співустя, свідчать про актуальність питання та потребують подальшого накопичення досвіду [10].

Мета дослідження: оцінити безпосередні й віддалені результати впровадженої методики хірургічного лікування хворих з приводу фіброзно-дегенеративного ХП з БГ.

\section{МАТЕРІАЛИ I МЕТОДИ ДОСЛІДЖЕННЯ}

У 2012 - 2016 рр. у відділенні загальної хірургії Івано-Франківської обласної клінічної лікарні оперовані 49 хворих з приводу ХП з БГ. Операція Фрея виконана у 25 (51\%) хворих, панкреатодуоденальна резекція за Whipple - у 6 (12,2\%), поздовжня панкреатоєюностомія 3 формуванням ГЕА - у 6 (12,2\%), операція Бегера в Бернській модифікації - у 3 (6,1\%), цистоєюностомія 3 накладенням ГСА - у 3 (6,1\%), біліодигестивні анастомози сформовані у 3 (6,1\%); цистопанкреатоєюностомія - у 2 (4,1\%), енуклеація кіст П3 здійснена в 1 хворого.

Проаналізовані результати лікування 25 (51\%) хворих 3 приводу фіброзно-дегенеративного ХП 3 БГ, у яких виконана операція Фрея. Чоловіків було 22 (88\%), жінок - 3 (12\%). Вік хворих від 33 до 67 років, у середньому $(47,46 \pm 2,66)$ року. У 13 (52\%) хворих виконано класичну операцію Фрея з формуванням ПЕА на петлі тонкої кишки, виключеній за Ру, у 4 (16\%) - операцію Фрея з накладанням ГЕА (група порівняння). У 8 (32\%) хворих використано запропоновану нами модифікацію (основна група) [11], що передбачала проведення резекційного етапу операції Фрея, на реконструктивному етапі - формування ПЕА на ізольованому сегменті тонкої кишки, додаткового дуоденоєюноанастомозу 3 дистальним кінцем сегмента тонкої кишки, виконання холецистектомії, накладання ГЄА бік у бік, відновлення прохідності травного каналу шляхом формування міжкишкового анастомозу за Ру.

Прототипом способу формування ПЕА з дуоденоєюноанастомозом 3 приводу фіброзно-дегенеративного ХП з БГ була методика, запропонована В. М. Копчаком і співавторами при виконанні поздовжньої панкреатоєюностомії [12].

Висічення тонкої кишки у вигляді сегмента за довжиною П3, формування панкреатоєюноанастомозу та анастомозування дистального кінця сегмента бік у бік з ДПК в проекції іiі великого сосочка забезпечувало фізіологічне надходження панкреатичного соку в ДПК, що запобігало виникненню ускладнень у вигляді дисфункції травного каналу. Часткове зашивання дистального кінця сегмента тонкої кишки запобігало рефлюксу вмісту кишечнику у протоку ПЗ.

БГ усували шляхом накладання ГСА бік у бік за Ру. Перевагами формування анастомозу бік у бік є збільшення його діаметра внаслідок розсічення СЖП у поздовжньому напрямку. Для цього використовували дистальний відділ тонкої кишки після висічення іiі сегмента. Для відновлення прохідності кишечнику накладали міжкишковий анастомоз за Ру на 70 - 80 см нижче ГЕА.

Після виконання резекційного етапу операції здійснювали ретельний гемостаз. Панкреатоєюноанастомоз за «щільної» тканини ПЗ формували 3 використанням однорядного безперервного шва за оригінальною методикою [13].

Для інтраопераційного визначення тиску у позапечінкових жовчних протоках використовували оригінальну методику. Залишковий тиск в СЖП в нормі становив 50 - 150 мм вод. ст. Тиск вище 160 мм вод. ст. свідчив про наявність БГ. Виділяли три ступеня БГ.

БГ І ступеня - тиск у СЖП підвищений до 190 мм вод. ст. Клінічні та лабораторні дані, що свідчили б про наявність БГ, відсутні.

БГ II ступеня - тиск у СЖП 190 250 мм вод. ст. Характерні порушення надходження жовчі у ДПК, транзиторна обтураційна жовтяниця.

БГ III ступеня - тиск у СЖП постійно перевищує 250 мм вод. ст. [14, 15].

Використовували класифікацію ХП, запропоновану О. О. Шалімовим (1997). Зміни протоки ПЗ оцінювали за Кембриджською класифікацією.

Для інструментальної діагностики застосовували ультразвукове дослідження (УЗД) 3 використанням апарата «Alpinion Ecube-9» (Корея) 3 конвексним датчиком 3 частотою 3,5 - 5 МГц, секторальним механічним датчиком 3 частотою $2,5-5$ МГц, лінійним електронним датчиком з частотою 7,5 - 10 МГц; езофагогастродуоденоскопію (ЕГДС) 3 використанням відеосистеми CV-70 («Olympus», Японія); ендоскопічну ретроградну панкреатикохолангіографію (ЕРПХГ) і папілосфінктеротомію (ПСТ) з використанням дуоденоскопів JF-E і TJF-V70 («Olympus», Японія), рентгенівського апарата 3 електронно-оптичним перетворювачем (ЕОП) («Siemens BV-300», Німеччина), спіральну комп'ютерну томографію (СКТ) 3 контрастним підсиленням (рентгенівський апарат «Siemens Somatom Emotion», Німеччина). Для магніторезонансної холангіопанкреатографіï (МРХПГ) використовували апарат «Siemens Magnetom Avanto» (Німеччина), напруженість магнітного поля 1,5 T. Протокол дослідження включав ізотропічний Т2 space 3 синхронізацією за диханням, з значно підвищеною контрастністю між рухомою жовчю і навколишніми тканинами. Для оцінки стану паренхіматозних органів використовували протоколи отримання Т2 зважених зображень, Т1 зважених зображень, дифузійнозважених зображень в сагітальних, корональних та поперечних проекціях 3 затримкою дихання та синхронізацією за диханням.

Трофологічний статус хворих визначали за товщиною складки шкі- 
ри в проекції триголового м'яза плеча, об'єму плеча на рівні двоголового м'яза та індексу маси тіла (IMT).

Віддалені результати хірургічного лікування оцінювали під час огляду хворих, проведення УзД та заповнення анкети модифікованого опитувальника SF-36, що дало можливість оцінити окремо фізичний та психоемоційний стан пацієнтів.

\section{РЕЗУЛЬТАТИ}

\section{ТА ÏХ ОБГОВОРЕННЯ}

Тривалість захворювання 3 моменту встановлення діагнозу до госпіталізації хворих обох груп становила у середньому $(5,6 \pm 0,25)$ року. Зловживання алкоголем як провідний чинник виникнення захворювання відзначене у 21 (84\%) хворого. Раніше з приводу гострого некротичного панкреатиту оперовані 6 (24\%) хворих. Цукровий діабет II типу середньої тяжкості і тяжкий в стадії субкомпенсації встановлений у 7 (28\%) хворих. Максимальний рівень глюкози у сироватці крові при госпіталізації становив 19,3 ммоль/л.

У хворих групи порівняння IMT до операції становив у середньому $(18,38 \pm 0,66)$ кг $/ \mathrm{M}^{2}$, товщина складки шкіри в проекції триголового м'яза плеча - $(1,45 \pm 0,08)$ см, об'єм плеча на рівні двоголового м'яза - (22,33 \pm $0,51)$ см. У хворих групи порівняння, яким виконана операція Фрея 3 ГЕА, IMT становив $(18,48 \pm 0,19)$ кг/ $\mathrm{M}^{2}$, товщина складки шкіри в проекції триголового м'яза плеча - $(1,55$ $\pm 0,05)$ см, об'єм плеча на рівні двоголового м'яза - $(21,83 \pm 0,64)$ см. У хворих основної групи IMT до операції становив $(18,7 \pm 0,99)$ кг $/ \mathrm{M}^{2}$, товщина складки шкіри в проекції триголового м'яза плеча - (1,33 \pm $0,12)$ см, об'єм плеча на рівні двоголового м'яза - $(22,25 \pm 0,77) \mathrm{cm}$.

До операції у хворих обох груп PHs становив (40,6 $\pm 2,0)$ ум. од., MHs - $(55,4 \pm 3,1)$ ум. од., ВР - $(35,1 \pm 7,8)$ ум. од.

Найбільш інформативним скринінговим методом діагностики вважали УЗД. За цим методом верифікували розміри ПЗ, зміни у паренхімі, наявність вірсунгоектазіі, вірсунголітіазу, розширення СЖП, жовчнокам'яної хвороби тощо. За даними допплерографічного картування визначали характер кровотоку по магістральних судинах гепатопанкреа- тобіліарної зони. В усіх хворих виявлені зміни паренхіми ПЗ відповідали характерним УзД ознакам фіброзно-дегенеративного ХП, з конкрементами в паренхімі П3, вірсунгоектазією, утворенням інтрапанкреатичних кіст в головці ПЗ, вірсунголітіазом, розширенням СЖП до 1,2 - 1,5 см. Жовчнокам'яна хвороба, ускладнена холедохолітіазом, діагностована у 2 (14,3\%) пацієнтів.

ЕРПХГ проведена у 12 (48\%) хворих за наявності клінічних ознак обтураційної жовтяниці та холангіту. За Кембриджською класифікацією, зміни протоки ПЗ відповідали III ступеню - у 3 (25\%), IV ступеню - у 9 (75\%) хворих.

У 6 хворих з приводу тубулярного стенозу СЖП та вірсунголітіазу проведені ендобіліарне стентування, балонна дилатація протоки ПЗ та неповна екстракція конкрементів. У 4 хворих з приводу препапілярної стриктури протоки ПЗ здійснені балонна дилатація протоки ПЗ та ендопанкреатичне стентування; в одного хворого додатково - літоекстракція конкрементів СЖП. У хворого з приводу тубулярного стенозу СЖП та холедохолітіазу виконали балонну дилатацію, екстракцію конкремента з СЖП та ендобіліарне стентування. Ще в одного хворого з приводу стенозу термінального відділу СЖП та протоки ПЗ здійснене ендобіліарне та ендопанкреатичне стентування.

За відсутності обтураційної жовтяниці у хворих 3 «щільною» тканиною ПЗ, вираженими фіброзно-дегенеративними змінами та масивними кальцифікатами в паренхімі головки ПЗ виконання транспапілярних втручань на протоці ПЗ вважали недоцільним [16].

Тривалість періоду від виконання транспапілярних ендоскопічних втручань до відкритого втручання від 5 діб до 1 року, що зумовлене необхідністю корекції холангіту, гіперглікеміі,, повторним виникненням обтураційної жовтяниці внаслідок інкрустації ендобіліарного стента, тимчасовою відмовою від хірургічного лікування, значним прогресуванням больового та диспептичного синдромів через порушення дієти.

МРПХГ проведена у 7 (28\%) хворих. Цей неінвазивний метод дозволяє отримати чітке просторове зображення внутрішньо- та позапе-

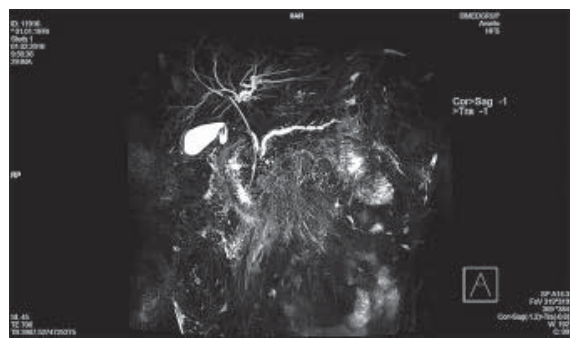

МРПХГ.

Фіброзно-дегенеративний ХП з БГ. Збільшення жовчного міхура, ендобіліарний стент у СЖП, дилатація протоки ПЗ до 0,7 см.

чінкових жовчних проток, жовчного міхура та протокової системи ПЗ без використання контрастної речовини (див. рисунок)

СКТ проведена у 4 (16\%) хворих, в усіх підтверджений діагноз калькульозного ХП, розширення протоки П3, наявність вірсунголітіазу та БГ.

Інтраопераційне вимірювання та реєстрацію тиску жовчі в СЖП проводили впродовж усього резекційного етапу операції Фрея. На початку оперативного втручання БГ I ступеня встановлена у 13 хворих. По завершенні резекційного етапу операції тиск був у межах норми, тому втручання на позапечінкових жовчних протоках у них не проводили. БГ II ступеня на початку операції відзначена у 7, III ступеня - у 5 хворих. Виконання резекційного етапу операції сприяло зниженню тиску жовчі у СЖП, проте, досягти його нормалізації не вдалося, тому оперативне втручання у цих хворих доповнене накладанням ГЕА за Ру.

У хворих групи порівняння тривалість класичної операції Фрея становила у середньому (198,8 \pm 22$)$ хв, операції Фрея з формуванням ГЕА $(250,83 \pm 40,3)$ хв, в основній групі $(298,13 \pm 37,9) \times$ хв.

В перші дні після операції у деяких хворих обох груп відзначали віраж амілаземії, підтікання невеликої кількості жовчі чи панкреатичного соку через дренажні трубки. Ці ускладнення усунуті за допомогою консервативних заходів і не впливали на перебіг післяопераційного періоду чи тяжкість стану хворих.

Тривалість лікування у стаціонарі після операції хворих групи порівняння становила $(10,6 \pm 0,7)$ дня, основної групи - $(13,2 \pm 0,5)$ дня. Всі пацієнти живі, виписані для продовження лікування за місцем прожи- 
вання. Через 1 рік спостереження в групі порівняння після виконання операції Фрея IMТ становив (24,4 \pm $0,58)$ кг $/ \mathrm{M}^{2}$, товщина складки шкіри в проекції триголового м'яза плеча - $(2,11 \pm 0,08)$ см, об'єм плеча на рівні двоголового м'яза - $(28,92 \pm 0,72)$ см; після виконання операції Фрея 3 формуванням ГСА ІМТ становив $(23,05 \pm 0,64)$ кг $/ \mathrm{M}^{2}$, товщина складки шкіри в проекції триголового м'яза плеча - $(2,1 \pm 0,08)$ см, об'єм плеча на рівні двоголового м'яза - (31,17 \pm $1,12)$ см. В основній групі через 1 рік

\section{תITEPATYPA/REFERENCES}

1. Yareshko VG, Mikheev YuA. Vybor metoda khirurgicheskogo lecheniya khronicheskogo pankreatita i ego oslozhneniy. XXIII z'izd khirurhiv Ukrainy. Klinichna khirurhiia, 2015:219-20. [In Russian].

2. di Sebastiano P, di Mola FF. Pathophysiology of Chronic Damage. In: Testoni PA, Mariani A, Arcidiacono PG, editors. Acute and Chronic Pancreatitis: New concepts and evidence-based approaches. Turin: Edizioni Minerva Medica, 2013:63-9.

3. Dobrov SD, Polyakevich AS, Blagitko EM, Tolstykh GN. Zhelchnaya gipertenziya u bol'nykh khronicheskim pankreatitom. Annaly khirurgicheskoy gepatologii. 2012;(4):35-8. [In Russian].

4. Ratchik VM, Gaydar YUA. Khirurgicheskaya korrektsiya oslozhnennykh form khronicheskogo pankreatita. Suchasna khirurgiya ta koloproktologiya. 2012;4 (4):53-7. [In Russian].

5. Büchler MW, Baer HU, Seiler C. Duodenum preserving resection of the head of the pancreas: a standard procedure in chronic pancreatitis. Chirurgie. 1997 Aprl;68(4):364-8.

6. Kopchak VM, Usenko AYu, Kopchak KV, Zelinskiy Al. Khirurgicheskaya anatomiya podzheludochnoy zhelezy. Kiev: Izdatelskiy dom «Askaniya», 2011. $141 \mathrm{~s}$. [In Russian].

7. Strate T, Taherpour Z, Bloechle C, Mann O, Bruhn JP, Schneider $\mathrm{C}$, et al. Long-term follow-up of a randomized trial comparing the Beger and Frey procedures for patients suffering from chronic pancreatitis. Ann Surg. 2005;241:591-8.

8. Vorobey AV, Shuleyko ACh, Orlovskiy YuN, Vizhinis Yul, Lagodich NA. Biliarnaya gipertenziya pri khronicheskom pankreatite. Novosti khirurgii. 2014;(4):408-15. [In Russian].
9. Galperin El, Dyuzheva TG, Akhaladze GG. KHronicheskiy pankreatit, rezetsiruyushchie i dreniruyushchie vmeshatelstva. Khirurgiya. Zhurnal im. NI Pirogova. 2006;(8):4-9 [In Russian].

10. Rezolyutsiya Plenuma Pravleniya Assotsiatsii khirurgov-gepatologov Rossii i stran SNG (Izhevsk 19 - 20 apr $2012 \mathrm{~g}$.) «Khronicheskiy pankreatit». Annaly khirurgicheskoy hepatologii. 2012;17(3):118-9. [In Russian].

11. Sposib khirurhichnoho likuvannia khronichnoho pankreatytu, uskladnenoho obturatsiinoiu zhovtianytseiu: pat. 93960 Ukraina. № u201404410; zaiavl. 24.04.2014; opubl. 27.10.2014, Biul. № 20 . [In Ukrainian].

12. Sposib khirurhichnoho likuvannia khronichnoho pankreatytu: pat. 45721 A Ukraina. № 2001064111; zaiavl. 14.08.2001; opubl. 15.04.2002, Biul. № 4 [In Ukrainian].

13. Sposib formuvannia pankreatoieiunoanastomozu: pat. 83028 Ukraina. № u201302157; zaiavl. 21.02.2013; opubl. 27.08.2013, Biul. № 16. [ [In Ukrainian].

14. Sposib vymiriuvannia tysku $\vee$ zahalnii zhovchovyvidnii prototsi: pat. 109547 Ukraina. № u201602279; zaiavl. 10.03.2016; opubl. 25.08.2016, Biul. № 16. [In Ukrainian].

15. Sposib khirurhichnoho likuvannia khronichnoho pankreatytu, uskladnenoho zhovchnokam'ianoiu khvoroboiu: pat. 101713 Ukraina. № u201503315; zaiavl. 09.04.2015; opubl. 25.09.2015, Biul № 18. [In Ukrainian].

16. Shevchuk IM, Pylypchuk VI, Gedzyk SM. Endoscopic transpapillary interventions in chronic pancreatitis. Klinichna khirurhiia. 2014;(3):19-22. [In Ukrainian]. 